\title{
Immunoglobulin Isotype-Specific Antibody Responses to Pneumococcal Polysaccharide Vaccine in Patients with Recurrent Bacterial Respiratory Tract Infections
}

\author{
LIEKE A. M. SANDERS, GER T. RIJKERS, ANNE-MARIE TENBERGEN-MEEKES, \\ MARLEEN M. VOORHORST-OGINK, AND BEN J. M. ZEGERS \\ Department of Immunology, University Hospital for Children, "Het Wilhelmina Kinderziekenhuis," \\ Utrecht, The Netherlands
}

\begin{abstract}
Anti-pneumococcal IgM, IgG1, IgG2, and IgA antibody titers
were determined in 61 pediatric patients with recurrent bacterial
respiratory tract infections. The patients were divided in those
with normal serum Ig levels (group I, $n=46$ ) and patients with
dysimmunoglobulinemia (group II, $n=15$ ). Antibody titers to
five pneumococcal serotypes ( $3,4,6 \mathrm{~A}, 9 \mathrm{~N}$, and 19F) of different
immunogenicity were determined by ELISA, before and $14 \mathrm{~d}$
after immunization with pneumococcal polysaccharide vaccine.
In the patients of group I, IgM responses did not vary between
the various serotypes. IgG1 antibodies reached high levels for
pneumococcal types 3,4, and $9 \mathrm{~N}$ compared with an adult
reference hyperimmune plasma pool, but remained low for the
weak immunogenic types $6 \mathrm{~A}$ and $19 \mathrm{~F}$. IgG2 antibody titers
remained low and were nearly absent in $20 / 46$ patients. The fold
increase in IgA was high, but the ultimate IgA antibody levels
remained low. IgA levels remained low to absent in $10 / 46$
patients. Two patients (4\%) of group I failed to show anti-
\end{abstract}
The defense against infections with encapsulated bacteria such as Streptococcus pneumoniae and Hib primarily depends on antibodies against the capsular polysaccharides of these microorganisms. A defective antibody response to polysaccharide antigens is found in infants up to $18-24$ mo and in patients after bone marrow transplantation or with diseases such as Wiskott-Aldrich syndrome and AIDS (1). Furthermore, aberrant anti-polysaccharide antibody responses are frequently found in patients with humoral immunodeficiency disease, for example, IgA or IgG2 deficiency (1-3).

The human antibody response upon immunization with polysaccharide vaccine normally involves $\operatorname{IgM}, \operatorname{IgG} 1, \operatorname{IgG} 2$, and $\operatorname{IgA}$ isotypes $(4,5)$. In adulthood, the IgG response to pneumococcal vaccine is mainly of the IgG2 isotype, but in infants

Received July 14, 1994; accepted January 26, 1995

Correspondence and reprint requests: E. A. M. Sanders, Department of Immunology, University Hospital for Children "Het Wilhelmina Kinderziekenhuis," P.O. Box 18009 3501 CA Utrecht, The Netherlands. pneumococcal antibodies of all Ig isotypes. In group II, 6/15 patients (40\%) made no anti-pneumococcal antibodies of any isotype, whereas the remaining patients made no $\operatorname{IgG} 2$ and/or IgA anti-pneumococcal antibodies. We conclude that the frequency of nonresponders to pneumococcal vaccination in patients with normal serum $\mathrm{Ig}$ is low (4\%). However, low $\operatorname{IgG} 2$ anti-pneumococcal levels are found in approximately $50 \%$ of the patients. In patients with dysimmunoglobulinemia, IgA and IgG2 responses were absent in virtually all patients, whereas $40 \%$ made no anti-pneumococcal antibodies of any isotype. (Pediatr Res 37: 812-819, 1995)

Abbreviations
CPS, common cell wall polysaccharide
Ab N, antibody nitrogen
Hib, Haemophilus influenzae type b

and children the $\operatorname{IgG}$ anti-polysaccharide antibodies predominantly reside in the IgG1 subclass $(4,5)$. The mechanisms that determine the localization of anti-polysaccharide antibodies in the IgG2 subclass are poorly understood. In childhood, $S$. pneumoniae is the primary pathogen involved in bacterial respiratory tract infections such as otitis media acuta and sinusitis $(6,7)$. In view of the increased susceptibility to infections with encapsulated bacteria such as $S$. pneumoniae, observed in children or in IgG2-deficient individuals, IgG1 anti-carbohydrate antibodies may be less protective compared with IgG2 antibodies $(4,8)$.

Some children (older than $2 \mathrm{y}$ ) remain highly susceptible to infections with $S$. pneumoniae, despite normal serum Ig levels, including IgG subclasses. They suffer from recurrent acute otitis media and sinopulmonary infections. We previously described deficient anti-pneumococcal antibody responses in a group of children with frequent recurrent bacterial upper respiratory tract infections (9). However, we (and others) found 
that only $10-15 \%$ of these infection-prone children had low to absent anti-polysaccharide antibodies $(9,10)$. We now investigated $\operatorname{IgM}, \operatorname{IgG} 1, \operatorname{IgG} 2$, and $\operatorname{IgA}$ responses to pneumococcal vaccine in a group of 46 children with normal serum Ig levels and recurrent bacterial respiratory tract infections. In addition, anti-pneumococcal antibody responses of 15 patients with humoral immunodeficiency (such as selective $\operatorname{IgA}$ or $\operatorname{IgG} 2$ deficiency) are described.

\section{METHODS}

Patients. Sixty-one patients aged 1.7-17.1 y were included in the study (Table 1). Between 1989 and 1990 the patients were referred to the department of immunology of our hospital by their pediatrician or otolaryngologist for immunologic evaluation. All patients suffered from recurrent acute otitis media/ otorrhea and recurrent sinusitis with purulent nasal discharge, foul smelling breath, and coughing for at least six to eight episodes per year (Table 1). During each episode the children had a fever of $>38.5^{\circ} \mathrm{C}$ for at least $24 \mathrm{~h}$ and general malaise. The patients finally improved only after antibiotic treatment and often needed prolonged courses of antibiotics. Some patients had documented invasive infections with $S$. pneumoniae or Hib (Table 1). Patients with allergy as the major source of symptoms were excluded from the study. Patients with anatomic abnormalities or recognized disease entities such as cystic fibrosis, granulocytopenia, or complement deficiency were also excluded from the study.

Parental consent was obtained for an intramuscular immunization with 23-valent pneumococcal vaccine (Pneumovax; Merck, Sharp and Dohme, Haarlem, The Netherlands) containing $25 \mu \mathrm{g}$ of 23 pneumococcal serotypes $(1,2,3,4,5,6 \mathrm{~B}, 7 \mathrm{~F}$, $8,9 \mathrm{~N}, 9 \mathrm{~V}, 10 \mathrm{~A}, 11 \mathrm{~A}, 12 \mathrm{~F}, 14,15 \mathrm{~B}, 17 \mathrm{~F}, 18 \mathrm{C}, 19 \mathrm{~F}, 19 \mathrm{~A}, 20$, $22 \mathrm{~F}, 23 \mathrm{~F}$, and $33 \mathrm{~F}$ ). Serum was obtained before and $14 \mathrm{~d}$ after vaccination and stored at $-80^{\circ} \mathrm{C}$ until use.

Determination of serum Ig. Concentrations of IgM, IgG subclasses, and $\operatorname{IgA}$ were determined on two or more occasions

Table 1. Clinical characteristics of patients with recurrent bacterial tract infections

\begin{tabular}{lcc}
\hline \multicolumn{1}{c}{ Characteristic } & Group I & Group II \\
\hline No. of patients & 46 & 15 \\
o: + & $27: 19$ & $7: 8$ \\
Age at Pvacc (y) & 4.4 & 6.3 \\
Range & $1.7-14.7$ & $2.3-17.1$ \\
Otitis media acuta/otorrhea & $45 / 46(98) *$ & $14 / 15(93)$ \\
Myringotomy/tubes & $37 / 46(80)$ & $13 / 15(87)$ \\
Adenoidectomy & $39 / 46(85)$ & $15 / 15(100)$ \\
Mastoidectomy & $16 / 46(35)$ & $5 / 15(33)$ \\
Severe hearing loss & $9 / 46(21)$ & $4 / 15(27)$ \\
Sinubronchitis & $46 / 46(100)$ & $15 / 15(100)$ \\
Antral lavage/antrostomy of maxillary sinus & $14 / 46(30)$ & $7 / 15(46)$ \\
Pneumonia & $18 / 46(39)$ & $11 / 15(73)$ \\
Bacteremia/sepsis (S.pn, Hib) & $2 / 46(4)$ & $1 / 15(7)$ \\
Arthritis/osteomyelitis (S. pn) & $1 / 46(2)$ & $1 / 15(7)$ \\
Meningitis (S.pn, Hib) & $4 / 46(9)$ & $2 / 15(13)$ \\
\hline
\end{tabular}

Clinical manifestations of 46 patients with normal serum immunoglobulins (group I) and 15 patients with dysimmunoglobulinemia (group II). Pvacc = pneumococcal vaccination, $S . p n=S$. pneumoniae. Sinusitis was documented by $\mathrm{x}$-ray a least once; pneumonia was always documented by $\mathrm{x}$-ray.

* Numbers in parentheses are percent. by radial immunodiffusion. A range of $2 \mathrm{SD}$ above to $2 \mathrm{SD}$ below the mean for age was considered normal $(11,12)$. Diphtheria and tetanus toxoid antibodies were determined as previously described (13). A titer of less than $0.1 \mathrm{U} / \mathrm{mL}$ for a fully immunized child was considered below normal (13). Anti-blood group isohemagglutinins anti-A and anti-B were determined by standard methods. Antibody titers below 1:16 after $2 \mathrm{y}$ of age were considered below normal. IgE was determined by ELISA.

Anti-pneumococcal antibody assay. Serum $\operatorname{IgM}, \operatorname{IgG} 1$, $\operatorname{IgG} 2$, and $\operatorname{IgA}$ anti-pneumococcal antibodies to five pneumococcal serotypes $(3,4,6 \mathrm{~A}, 9 \mathrm{~N}$, and $19 \mathrm{~F})$ were quantified by ELISA before and $14 \mathrm{~d}$ after immunization with pneumococcal vaccine. Pre- and postimmunization serum samples from individuals were analyzed simultaneously (and in duplicate). All serum samples were preincubated overnight, with excess free CPS to remove anti-CPS antibodies (14). A standard serum from a normal nonvaccinated adult was included in every ELISA run as a control. If the results of the control deviated by more than $10 \%$ from the mean, the whole ELISA was repeated. Microtiter plates (Greiner Labortechnik, Langerthal, Germany) were coated with pneumococcal capsular polysaccharides (American Type Culture Collection, Rockville, MD, $10 \mu \mathrm{g}$ / $\mathrm{mL}$ ) in saline solution at $37^{\circ} \mathrm{C}$, overnight. Subsequently, plates were washed (PBS, Tween 20,0.05\%, vol/vol), and incubated for $2 \mathrm{~h}$ at $37^{\circ} \mathrm{C}$ with serial dilutions of serum samples in PBS, $0.05 \%$ Tween $20,1 \%$ bovine serum albumin (vol/vol). After washing (PBS-Tween-BSA), the plates were incubated for $2 \mathrm{~h}$ $\left(37^{\circ} \mathrm{C}\right)$, with alkaline phosphatase-labeled goat anti-human $\operatorname{IgM}$ (2492, lot no. 5701), goat anti-human IgA (2491, lot no. 2601) antibodies (Tago, Inc., Burlingame, CA), peroxidaselabeled, subclass-specific murine anti-human IgG1 (MH161$1 \mathrm{ME}$, lot no. 1328-04H01), or IgG2 (MH162-1ME, lot no. 1329-05-01) monoclonals (Central Laboratory of the Netherlands Red Cross Blood Transfusion Service (CLB), Amsterdam, The Netherlands). After washing and incubation with enzyme substrate for $10-20 \mathrm{~min}, 37^{\circ} \mathrm{C}$, absorbance was read using a Titertek Multiscan (Flow Laboratories, Irvine, CA). The antibody concentrations in the serum samples were calculated by comparison with a human hyperimmune plasma pool (15). This plasma pool contains $2648 \mathrm{ng}$ of $\mathrm{Ab} \mathrm{N} / \mathrm{mL}$ for serotype 3; $1196 \mathrm{ng} \mathrm{Ab} \mathrm{N} / \mathrm{mL}$ for serotype 4; $539 \mathrm{ng} \mathrm{Ab} \mathrm{N} / \mathrm{mL}$ for group 6; $927 \mathrm{ng} \mathrm{Ab} \mathrm{N} / \mathrm{mL}$ for group 9 and $440 \mathrm{ng} \mathrm{Ab} \mathrm{N} / \mathrm{mL}$ for group 19 as determined by RIA (15).

Ideally, the definition of normal responses at different ages requires a representative group of healthy age-matched controls, immunized with pneumococcal vaccine. However, at the present no such group is available, nor are normal IgM, IgG1, $\operatorname{IgG2}$, and $\operatorname{IgA}$ values after pneumococcal vaccination both in adults and children. For this reason, we have chosen to express antibody concentrations of patient samples relative to the reference adult hyperimmune plasma pool of 112 healthy adults immunized with pneumococcal vaccine (15). The reference pool was assigned $100 \mathrm{U} / \mathrm{mL}(100 \%)$ for each serotype.

Evaluation of antibody responses to pneumococcal polysaccharides. The fold increase was calculated by dividing the postvaccination titer by the preimmunization titer. The response to an individual pneumococcal serotype was considered 
low to absent if the postimmunization titer remained below 20 $\mathrm{U} / \mathrm{mL}$ (i.e. $<20 \%$ of the antibody concentration in the reference hyperimmune plasma pool of healthy adult volunteers) $(9,15)$.

Statistical analysis. Pearsson and Spearman rank correlation coefficients were determined between age and pre- and postimmunization levels, and between Ig isotype specific antipneumococcal responses and corresponding serum levels of total IgM, IgG1, IgG2, and IgA. Because anti-pneumococcal antibody distributions varied widely between individuals, log transformed values were used in calculations of means of responses to each pneumococcal serotype (geometric mean \pm SEM).

\section{RESULTS}

Patients serum Ig. Forty-six patients had serum IgM, IgG, IgA, and IgG subclass levels within or above the normal range of our laboratory (mean for age values $\pm 2 \mathrm{SD}$ ). These patients were designated as group I. Three patients of group I had strongly elevated total serum IgG, and two of them also had elevated total $\operatorname{IgM}$ and/or IgA serum levels. One of these patients had bronchiectasis (patient I.45 of group I; Fig. 1). Although the IgG1 and IgG2 subclass levels of group I were within the normal range, $15 / 46$ children (30\%) had serum IgG2 levels between 1 and 2 SD below the mean for age. Two patients had elevated IgE levels. Bronchial hyperreactivity was present in $6 / 46$ patients $(13 \%)$.

Fifteen patients had various forms of dysimmunoglobulinemia such as IgA or IgG2 deficiency (Table 2). These patients were designated as group II. One of them (patient II.2 of group II; Fig, 2 and Table 2) had mildly elevated IgE and recurrent wheezing. Three additional patients $(20 \%)$ had bronchial hyperreactivity without atopic disease.

Patients clinical history. The clinical characteristics of the two groups of patients are presented in Table 1 . In most patients, the history of respiratory tract infections typically started between 6 and 12 mo of age. The mean age of the 46 patients of group I was younger than that of group II (4.4 versus $6.3 \mathrm{y}$ ). A family history of an immune deficiency disorder was present in a boy of group I (patient I.21; Fig. 1), who had an older brother and sister with IgG2-IgG4 deficiency and selective antibody deficiency to polysaccharide antigens (patients II.9 and II.10; Table 2 and Fig. 2). One girl (patient I.15 of group I; Fig. 1) had Fallot's tetralogy.

All patients suffered from frequent recurrent otitis media acuta/otorrhea and recurrent sinusitis. Surgical procedures such as adenoidectomy, myringotomies with polyethylene tube placement, mastoidectomy, lavage, or antrostomy of the maxillary sinuses had been performed in the majority of the patients (Table 1). Pneumonia, confirmed by chest radiography, was observed in $39 \%$ of patients of group I but more often in group II $(73 \%$, Kruskall-Wallis $p=0.014)$. Invasive infections with $S$. pneumoniae or Hib were similar in both groups (Table 1).

Isohemagglutinins, anti-tetanus and anti-diphtheria toxoid antibodies. All patients of both groups had normal anti-tetanus and anti-diphtheria antibody titers according to their immuni-
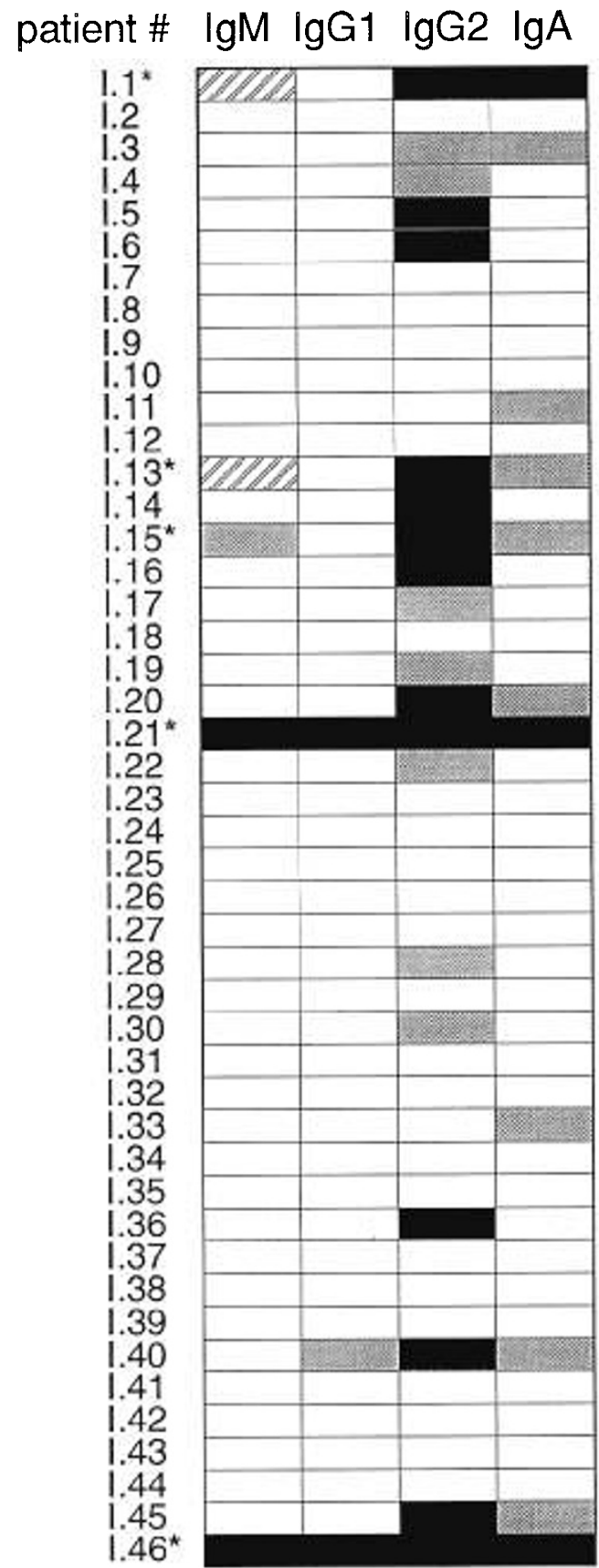

Figure 1. Anti-pneumococcal antibody IgM, IgG1, IgG2, and IgA titers $14 \mathrm{~d}$ after immunization with pneumococcal vaccine of 46 patients with recurrent respiratory tract infections and normal serum Ig. Forty-six patients with normal serum Ig and recurrent bacterial respiratory tract infections were immunized with pneumococcal vaccine. Anti-pneumococcal antibody titers (IgM, IgG1, $\operatorname{IgG} 2$, and $\operatorname{IgA}$ ) before and $14 \mathrm{~d}$ after immunization to five pneumococcal serotypes were determined by ELISA (see text). Antibody titers that remained below $30 \mathrm{U} / \mathrm{mL}$ (hatched), $20 \mathrm{U} / \mathrm{mL}$ (shaded), and $10 \mathrm{U} / \mathrm{mL}$ (black) to four to five of five pneumococcal serotypes are shown. Patients are numbered consecutively according to age; patient $\mathrm{I} .1$ was $1.7 \mathrm{y}$ and patient $\mathrm{I} .46$ was $14.7 \mathrm{y}$. An asterisk designates patients who were described as nonresponders in a previous article (9).

zation status (results not shown) (9). Two patients of group I (I.21 and I.46; Fig. 1) who were both un-responsive to pneumococcal vaccine had low isohemagglutinin levels. Six of the 15 patients of group II (II.2, II.9, II.10, II.11, II.12, and II.15; Table 2 and Fig. 2) had low isohemagglutinin levels. Five of 
Table 2. Serumimmunoglobulin levels in g/liter of 15 patients with dysimmunoglobulinemia

\begin{tabular}{|c|c|c|c|c|c|c|c|c|c|c|}
\hline Patient & Age & Sex & $\operatorname{IgM}$ & $\operatorname{IgG}$ & $\operatorname{IgA}$ & IgG1 & $\mathrm{IgG} 2$ & $\operatorname{lgG3}$ & IgG4 & Diagnoses \\
\hline II.1 & 2.3 & $q$ & 1.2 & 9.1 & 1.6 & 10.5 & 0.5 & 0.1 & $<0.1$ & Low IgG2, IgG3 \\
\hline $\mathrm{II} .2$ & 2.8 & $q$ & 0.5 & 6.7 & 0.04 & 3.7 & 1.3 & 0.4 & 0.2 & IgA def (transient)* \\
\hline II. 3 & 3.1 & $q$ & 2.0 & 10.1 & 0.2 & 7.6 & nd & 0.5 & $<0.1$ & $\mathrm{IgG} 2 \mathrm{def}$ \\
\hline II.4 & 3.2 & $\delta$ & 0.9 & 15.1 & nd & 10.5 & 2.9 & $<0.1$ & 0.3 & $\operatorname{IgA}, \operatorname{IgG} 3$ def \\
\hline II. 5 & 5.0 & q & 2.0 & 17.8 & nd & 17.4 & 2.5 & 0.3 & 0.3 & IgA def \\
\hline II. 6 & 6.1 & $\sigma$ & 0.8 & 9.3 & 0.05 & 7.0 & 1.1 & 0.2 & 0.1 & IgA def (transient)* \\
\hline II. 7 & 6.5 & $\delta$ & 0.3 & 8.2 & nd & 5.5 & 1.1 & 0.2 & 0.2 & IgA def \\
\hline II. 8 & 6.5 & $\delta$ & 2.1 & 9.1 & 0.3 & 8.5 & nd & 0.4 & $<0.1$ & $\operatorname{lgG} 2 \mathrm{def}$ \\
\hline II.9 & 7.2 & 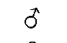 & 2.1 & 8.4 & 0.3 & 7.7 & 0.1 & 0.2 & $<0.1$ & IgG2 def* \\
\hline II.10 & 8.9 & q & 1.0 & 11.8 & 1.6 & 7.9 & 0.2 & 0.1 & $<0.1$ & IgG2 def* \\
\hline II.11 & 9.5 & $q$ & 1.1 & 2.3 & nd & 3.0 & nd & 0.1 & $<0.1$ & Hypogamma* \\
\hline II.12 & 10.2 & o & 0.2 & 7.7 & 0.3 & 8.5 & 0.4 & 0.5 & $<0.1$ & $\operatorname{IgG} 2 \operatorname{def}^{*}$ \\
\hline II.13 & 10.4 & $q$ & 0.2 & 7.5 & nd & 8.3 & 0.5 & 0.5 & $<0.1$ & $\operatorname{IgA}, \operatorname{lgG} 2 \operatorname{def} \dagger$ \\
\hline II.14 & 11.0 & $\hat{0}$ & 0.9 & 9.4 & nd & 9.7 & 4.2 & 1.0 & $<0.1$ & igA def $\dagger$ \\
\hline II.15 & 17.1 & 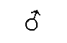 & 1.2 & 6.2 & 1.2 & 2.9 & 3.1 & 0.3 & $<0.1$ & Low IgG1* \\
\hline
\end{tabular}

Age (y) and serum immunoglobulins of 15 patients with recurrent respiratory tract infections and dysimmunoglobulinemia. Immunoglobulin titers are expressed in g/liter. n.d. $=$ not detectable.

* Patients with low isohemagglutinins levels (below 1:16).

$\dagger$ Patients with $\mathrm{AB}$ blood group.

patient \# $\lg M \lg G 1 \lg G 2 \lg A$

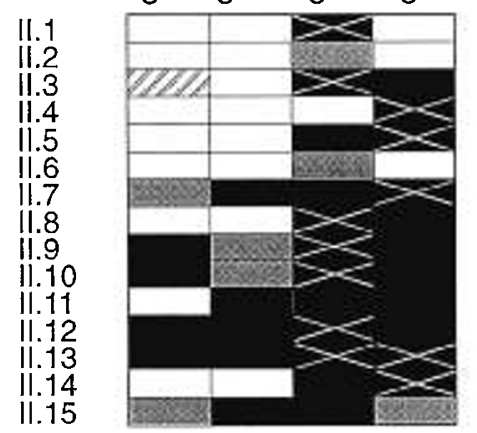

low lgG2, IgG3 transient $\lg A$ deficiency $\lg G 2$ deficiency
$\lg A$, lgG3 deficiency $\lg A$ deficiency transient $\lg A$ deficiency $\lg A$ deficiency IgG2 deficiency IgG2 deficiency IgG2 deficiency hypogammaglobulinemia IgG2 deficiency $\lg A, \lg G 2$ deficiency $\lg A$ deficiency low IgG1

Figure 2. Anti-pneumococcal antibody $\operatorname{IgM}$, IgG1, IgG2, and IgA titers $14 \mathrm{~d}$ after immunization with pneumococcal vaccine of 15 patients with dysimmunoglobulinemia and recurrent respiratory tract infections. Anti-pneumococcal antibody (IgM, IgG1, IgG2, and IgA) titers, before and $14 \mathrm{~d}$ after immunization to five pneumococcal serotypes, were determined by ELISA (see text). Antibody titers that remained below $30 \mathrm{U} / \mathrm{ml}$ (hatched), $20 \mathrm{U} / \mathrm{mL}$ (shaded), and $10 \mathrm{U} / \mathrm{mL}$ (black) to four to five of five pneumococcal serotypes are shown. Patients are numbered consecutively according to age; patient II.1 was $2.3 \mathrm{y}$ and patient II.15 was 17.1 y. A diagonal crossed box indicates a deficiency of corresponding isotype or subclass. An asterisk designates patients who were described as nonresponders in a previous article (9).

these six patients were unresponsive to pneumococcal vaccination (Fig. 2). During follow-up, the IgA deficiency of one patient (patient II.1; Table 2 and Fig. 2) turned out to be transient. When she was 4 y of age, her IgA was within normal levels and so were her isohemagglutinin levels. Two patients of group II (II.13 and II.14; Table 2 and Fig. 2) had blood group AB.

Anti-pneumococcal antibody levels. Ig isotype specific IgM, IgG1, IgG2, and IgA antibody responses to five pneumococcal serotypes were measured. We tested three strong immunogenic serotypes $(3,4$, and $9 \mathrm{~N})$, one intermediate and age-dependent serotype (19F), and a weak immunogenic serotype (6A) (16). These five serotypes frequently cause childhood infections with $S$. pneumoniae (17). Geometric mean preand postimmunization antibody titers (geometric mean \pm SEM), and the mean fold increase of both groups of patients are presented in Figure 3. No significant correlations between age and pre- and postimmunization antibody levels were observed $(p>0.05)$. There was no relation between IgM, IgG1, $\operatorname{IgG} 2$, and $\operatorname{IgA}$ isotype-specific anti-pneumococcal antibody responses and total serum levels of these isotypes (Pearsson and Spearman rank correlation coefficients). Specifically, we could not confirm the observation of Siber et al. (18) who found a relation between $\operatorname{lgG} 2$ serum levels and the mean antibody responses to pneumococcal antigens as well as the Hib capsular antigen, as determined by RIA.

In the patients with normal serum Ig, the mean preimmunization anti-pneumococcal IgM levels were between 20 and 50 $\mathrm{U} / \mathrm{mL}$ compared with the adult hyperimmune reference pool (Fig. 3). The mean fold increase for IgM was 2.0-2.6 for all five serotypes, including both strong and weak immunogenic types. Mean postimmunization IgM levels above $100 \mathrm{U} / \mathrm{mL}$ were observed for serotype 3 , and the other four serotypes reached levels between 60 and $90 \mathrm{U} / \mathrm{mL}$. Thus, postimmunization anti-pneumococcal IgM levels of group I patients in general were comparable to the adult reference pool.

The mean postimmunization anti-pneumococcal IgG1 levels were higher than those observed in the adult control plasma pool for the strong immunogenic types; IgG1 reached levels above $200 \mathrm{U} / \mathrm{mL}$ for type 3 and more than $100 \mathrm{U} / \mathrm{mL}$ for types 4 and $9 \mathrm{~N}$. However, in case of weak immunogenic serotypes, the mean IgG1 levels remained below the adult control pool ( 25 and $50 \mathrm{U} / \mathrm{mL}$ for $6 \mathrm{~A}$ and $19 \mathrm{~F}$, respectively).

The most striking finding of this study were the very low to absent IgG2 anti-polysaccharide antibody titers in the patient population, despite normal total serum $\operatorname{IgG} 2$ levels; the mean anti-pneumococcal IgG2 levels remained $<20 \mathrm{U} / \mathrm{mL}$ even for the strong immunogenic serotypes $(3,4$, and $9 \mathrm{~N})$, and $<5$ $\mathrm{U} / \mathrm{mL}$ (often undetectable) for $6 \mathrm{~A}$ and $19 \mathrm{~F}$.

$\operatorname{IgA}$ antibodies were low to absent in preimmunization sera. However, after vaccination, considerable increases were observed; more than a 10-fold increase was observed for types 4 and $9 \mathrm{~N}$, a 7-fold increase for types $6 \mathrm{~A}$ and $9 \mathrm{~N}$, and 5-fold for type 3, which showed the highest preimmunization level. The mean postimmunization IgA levels, however, remained well 

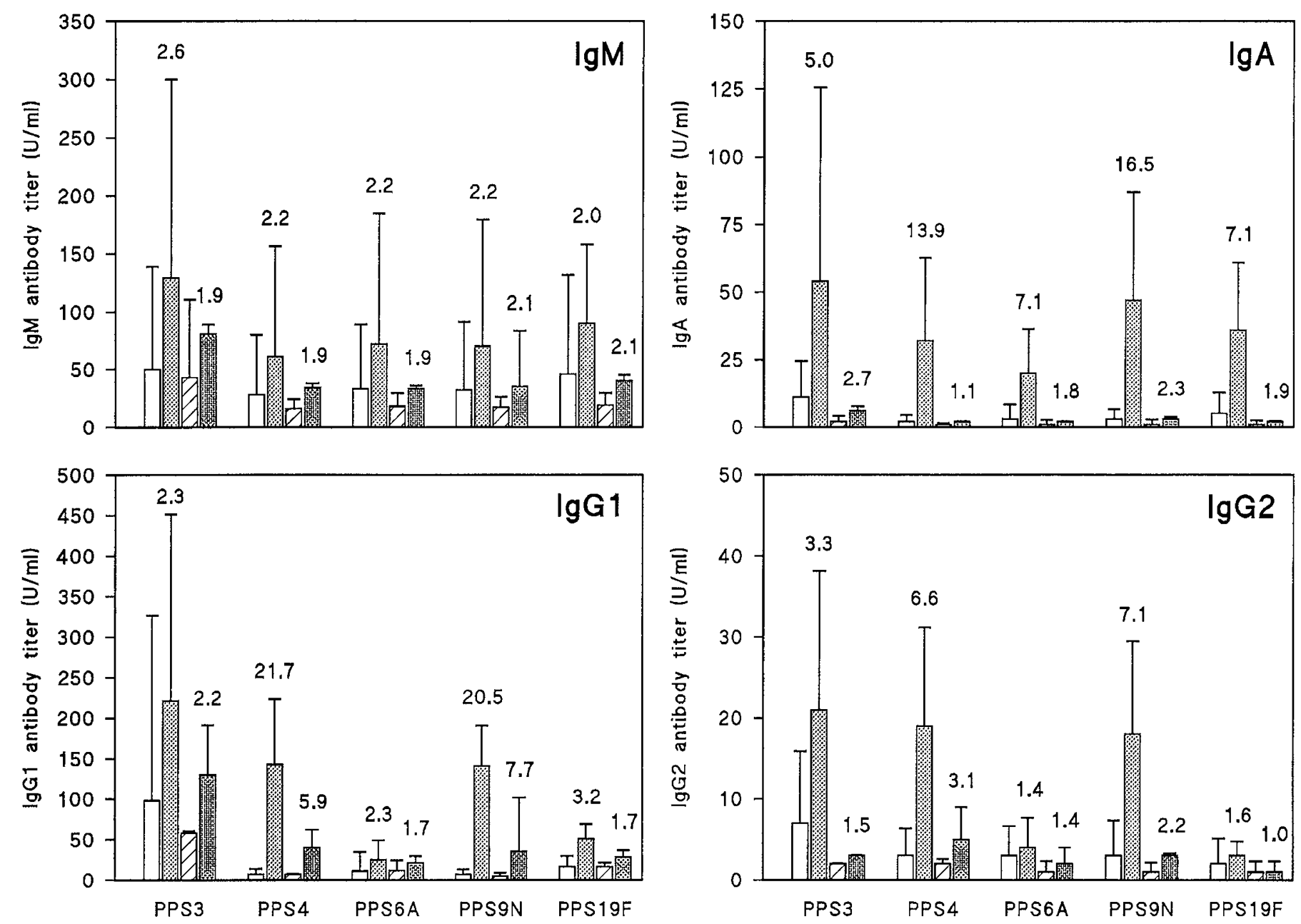

Figure 3. Pre- and postimmunization mean anti-pneumococcal antibody titers of 46 patients with normal serum Ig and 15 patients with humoral immunodeficiency. Forty-six patients with normal serum Ig (group I) and 15 patients with dysimmunoglobulinemia (group II) were immunized with pneumococcal vaccine. Geometric mean \pm SEM anti-pneumococcal antibody titers (IgM, IgG1, IgG2, and $\operatorname{IgA}$ ) before and $14 \mathrm{~d}$ after immunization are shown, together with the mean fold increase. The mean fold increase is shown above the bars of mean antibody concentration after $14 \mathrm{~d}$. Antibody titers to five pneumococcal serotypes were determined $(3,4,6 \mathrm{~A}, 9 \mathrm{~N}$, and 19F). Open and light-shaded bars represent pre- and postimmunization antibody titers of group I; hatched and dark-shaded that of group II.

below the adult reference pool: about $50 \mathrm{U} / \mathrm{mL}$ for types 3 and $9 \mathrm{~N}, 30-50 \mathrm{U} / \mathrm{mL}$ for types 4 , and $19 \mathrm{~F}$ and low $(20 \mathrm{U} / \mathrm{mL})$ for type $6 \mathrm{~A}$.

In conclusion, in children with recurrent infections and normal serum Ig levels, anti-pneumococcal IgM and IgG1 responses seem to be comparable to the adult reference pool (at least for the well immunogenic serotypes), whereas IgA and IgG2 antibody titers remained low.

In the patients of group II with dysimmunoglobulinemia, the mean postimmunization levels were mostly lower than group I (Fig. 3), due to the presence of several patients who had low to absent antibody titers of all isotypes (see also Fig. 2, as discussed below). Obviously, in a group of patients with either $\operatorname{IgA}$ or IgG2 deficiency, mean anti-pneumococcal IgA and $\operatorname{lgG} 2$ levels remained low.

Isotype and IgG subclass responses of individual patients of group I. We previously described five patients with normal serum Ig levels and a defective anti-pneumococcal antibody response (defined as antibody titers of $<20 \mathrm{U} / \mathrm{mL}$ for five to seven out of seven tested pneumococcal serotypes) (9). These patients are included in group I (patients I.1, I.13, I.15, I.21, and I.46; Fig. 1). Analysis of Ig isotype and IgG subclass distribution of anti-pneumococcal antibodies revealed that two of these five patients (I.21 and I.46; Fig. 1) failed to generate responses in all Ig isotypes to all five serotypes. In the other three patients (I.1, I.13, and I.15; Fig. 1), the postimmunization IgG2 and IgA antibody levels remained $<20 \mathrm{U} / \mathrm{mL}$, and IgM responses remained below $30 \mathrm{U} / \mathrm{mL}$ for all pneumococcal serotypes that were evaluated (Fig. 1). We now found that, apart from these five patients, in an additional 15 patients, in which the total anti-pneumococcal antibody response as such was not defective, the postimmunization IgG2 anti-pneumococcal antibody levels remained low to absent $(<20 \mathrm{U} / \mathrm{mL})$. In four of these 15 patients, anti-pneumococcal IgA antibody levels also remained $<20 \mathrm{U} / \mathrm{mL}$, whereas one patient (patient I.40; Fig. 1) also had IgG1 levels $<20 \mathrm{U} / \mathrm{mL}$. This patient, who was previously described as a responder patient, showed only (high) IgM responses. Two other patients (I.11 and I.33; Fig. 1) had a selective IgA anti-pneumococcal polysaccharide deficiency. 
Isotype and IgG subclass responses of individual patients of group II. As expected, deficient anti-pneumococcal responses were observed frequently in patients of group II (Fig. 2). Six of the 15 patients $(40 \%)$ had postimmunization antipneumococcal antibody levels of $<20 \mathrm{U} / \mathrm{mL}$ for all isotypes. Five of these six patients have already been described as nonresponders to pneumococcal vaccine in a former study (patients II.7, II.9, II.10, II.13, and II.15; Fig. 2 and Table 2) (9). A sixth patient (patient II.12; Fig. 2 and Table 2) with IgG2 deficiency has not been described before. This boy suffered from the invasive infections pneumococcal arthritis, bacteremia, and streptococcal endocarditis (apart from his chronic recurrent otorrhea and sinubronchitis). The IgM responses of the remaining nine patients were in the same range compared with group I (data not shown). Of note is patient II.11 of group II (Table 2 and Fig. 2), previously described as hypogammaglobulinemic but responding to pneumococcal vaccine (9). The anti-pneumococcal antibody response was restricted to $\operatorname{IgM}$ antibodies, therefore resembling that patient I.40 of group I as described above (Fig. 1). IgM responses in hypogammaglobulinemic patients have previously been observed (19). IgG1 anti-pneumococcal levels in the "responder" patients of group II were comparable to those of group I (data not shown). All but one patient (patient II.4; Fig. 2 and Table 2) failed to make IgG2 anti-carbohydrate antibodies. This patient was IgA- and IgG3-deficient, but had high serum IgG2 levels (Table 2). A deficient IgA anti-polysaccharide response was found in all dysimmunoglobulinemic patients of group II, except for the two patients whose serum IgA level increased toward normal levels during follow-up and whose IgA deficiency turned out to be transient (patients II. 2 and II.6; Fig. 2 and Table 2), and a third patient with low IgG2 and IgG3 levels (patient II.1; Fig. 2 and Table 2). Two siblings with nondetectable serum IgG2 but normal serum IgA levels, however, failed to make $\operatorname{IgA}$ anti-polysaccharide antibodies upon immunization with pneumococcal vaccine (patients II.3 and II.8; Fig. 2 and Table 2).

\section{DISCUSSION}

The effective removal of (encapsulated) bacteria requires phagocytosis of opsonized bacteria, a process that depends on the efficient interaction between anticapsular antibodies and $\mathrm{Fc}$ receptors, as well as complement and complement receptors (20). Specific antibodies to the bacterial capsular polysaccharides play a crucial role in this process, and their presence, as a result from primary infection, vaccination or crossimmunization, may prevent reinfection.

The immune response to pneumococcal polysaccharides normally involves IgM, IgG1, IgG2, and IgA Ig isotypes. We found that, in a childhood population with frequent infections with encapsulated bacteria such as $S$. pneumoniae, aberrant responses to pneumococcal vaccine were frequently observed. Although low to absent antibody responses of all isotypes were observed in only $2 / 46(4 \%)$ infection-prone patients with normal serum Ig, low to absent anti-pneumococcal IgG2 (20/46, $43 \%$ ) and/or $\operatorname{IgA}$ responses $(10 / 46,22 \%)$ were common. We did not investigate the $\mathrm{G} 2 \mathrm{~m}(23)$ allotypes of the patients in relation to the $\operatorname{IgG} 2$ responses (21). However, in previous studies, low IgG2 levels in infection-prone children were not related to the $\mathrm{G} 2 \mathrm{~m}(23)$ allotype (22).

In contrast to patients with normal serum Ig levels, aberrant responses to pneumococcal vaccine were frequently observed in infection prone patients with humoral immunodeficiency like $\operatorname{IgA}$ and/or IgG subclass deficiency; absent responses of all isotypes were observed in $6 / 15$ patients $(40 \%)$. These patients and their clinical history have been described previously (9). Furthermore, almost all (14/15) patients with humoral immunodeficiency failed to show IgG2 anti-pneumococcal responses. IgA responses were absent in $12 / 15(80 \%)$ of the patients, with the exception of one patient with low IgG2 and IgG3 levels, and two patients whose IgA deficiency turned out to be transient. The observed frequencies of absent antibody responses in $4 \%$ of infection-prone patients with normal serum Ig, and $40 \%$ of patients with IgA and/or IgG subclass deficiency are similar to those observed in a recent study by Gross et al. (23). Furthermore, the results of our study indicate that, next to the observation that some patients lack antipneumococcal antibody responses of all isotypes, an inability to make $\operatorname{IgG} 2$ or IgA antibodies also appears to define a clinical entity of high susceptibility for infections with $S$. pneumoniae. This, despite the fact that these patients do have IgG1 (and IgM responses).

Although the seemingly superiority of IgG2 anti-pneumococcal carbohydrate antibodies compared with IgG1 antibodies remains to be fully explained, clinical observations support the hypothesis of possible advantages of anti-carbohydrate antibodies localized in the $\operatorname{IgG} 2$ subclass $(3,8)$. For instance, otitis-prone children have similar IgG1 anti-pneumococcal antibody levels compared with age-matched controls, but lower IgG2 levels to some pneumococcal polysaccharides (8). Furthermore, $\operatorname{IgG1}$ and $\operatorname{IgG} 2$ anti-carbohydrate antibodies may display different avidity for polysaccharide antigens (24). For example, the relative avidity of $\operatorname{lgG} 2$ antibodies for pneumococcal serotype 3 was shown to be superior to the IgG1 subclass (24). Avidity of a given antibody, rather than its concentration, may determine clinical protection from disease $(25,26)$.

Until recently, it was emphasized that IgG1 is much more effective in activating the classical complement pathway compared with $\operatorname{IgG} 2$ (27). $\operatorname{IgG} 2$ activation of the classical pathway is variable. However, $\operatorname{IgG} 2$ seems to be superior to other $\operatorname{IgG}$ isotypes in activation of the alternative pathway, in the presence of high epitope density and antibody/antigen equivalence or antibody excess $(28,29)$. High antigen concentrations and epitope density are typical for repetitive capsular polysaccharide antigens present on the surface of encapsulated bacteria.

In (opsono)phagocytic assays, both IgG1 and $\operatorname{IgG} 2$ antibodies are effective $(30,31)$. However, in some studies, using encapsulated bacteria, the opsonic capacity of IgG1 anticapsular antibodies were superior to IgG2 (phagocytosis of Hib) (30, 32 ), whereas in others IgG2 antibodies were found to be superior to IgG1 (S. pneumoniae and group B Streptococcus type III) $(31,33)$. In a study of Chudwin et al. (34), opsonic activity for $S$. pneumoniae correlated with $\operatorname{IgG} 2$ antibody concentrations rather than with IgG1. Phagocytosis of bacteria like S. pneumoniae (31) or type III Streptococcus group B (33) 
may be more dependent on IgG2 compared with Hib $(30,32)$. It was also observed that efficient opsonization of $S$. pneumoniae by $\operatorname{IgG} 1$ requires complement, whereas $\operatorname{IgG} 2$ may facilitate phagocytosis independent of complement and is mediated by the Fc part of the molecule (31).

The fact remains that IgG1 interacts better with Fc receptors for $\operatorname{IgG}(\mathrm{Fc} \gamma-\mathrm{R})$ than $\operatorname{IgG} 2(35)$. However, in most studies on IgG1- and IgG2-mediated phagocytosis of bacteria by granulocytes, the allotype of the $\mathrm{Fc}$ receptor for $\mathrm{IgG} 2$ expressed by the granulocytes (Fc $\gamma$ IIIa, CD32), has not been taken into account $(30,31,33)$. The two allotypes of the Fc receptor for $\mathrm{IgG} 2$ on phagocytic cells differ in the interaction with complexed IgG2 (35) and in phagocytic capacities $(32,36)$. Consequently, the results of phagocytic assays in the past, comparing anti-polysaccharide IgG1 and IgG2-mediated phagocytosis of encapsulated bacteria, may be largely biased by the (at the time unknown) Fc $\gamma$ RIIIa phenotype of the donor granulocytes used in the assay.

Apart from deficient anti-pneumococcal IgG2 responses, deficient serum IgA responses were frequently observed. In preimmunization sera, anti-pneumococcal IgA levels are low to undetectable. Upon vaccination, large increases of antipneumococcal IgA antibodies were observed. Although we did not investigate IgA subclasses, the serum IgA responses to bacterial polysaccharide antigens (S. pneumoniae, Hib, and Neisseria meningitidis) are reported to be primarily polymeric and of the IgA2 isotype (37). Studies on the functional role of serum IgA provided evidence that IgA has opsonizing qualities and stimulates phagocytosis of bacteria $(38,39)$. Stewart and Kerr (40) report that IgA induces a respiratory burst via the Fc receptor for $\operatorname{IgA}, \mathrm{Fc} \alpha$, which was found to be even greater than the burst elicited by an equivalent concentration of IgG. Furthermore, $\operatorname{IgA}$ seems to be the best activator of the alternative complement pathway, which was found to be independent of epitope density and antigen/antibody ratio (28).

In contrast to $\operatorname{IgG}$ and $\operatorname{IgA}$ responses, $\operatorname{IgM}$ responses were relatively normal in most patients, irrespective of the immunogenicity of the pneumococcal serotype. Apart from 5/46 patients of group I and 6/15 patients of group II, all patients showed anti-pneumococcal IgM levels to both strongly and weakly immunogenic serotypes. The function of $\operatorname{IgM}$ may be mainly bactericidal via complement-mediated lysis, but IgM is probably less effective than IgG in both opsonization (Hib) (41, $42)$ and protection from pneumococcal disease $(31,43)$. Several investigators failed to demonstrate a significant correlation between IgM anti-pneumococcal antibodies and opsonic activity $(31,43)$

The frequent combination of low $\operatorname{IgG} 2$ and $\operatorname{IgA}$ antipolysaccharide antibody responses in childhood patients with recurrent bacterial infections suggests a shared common underlying mechanism in the regulation of expression of the heavy chain genes. The low IgG2 and IgA responses to pneumococcal vaccine may be due to a delay of these latematurating isotypes. Long-term follow-up is necessary to distinguish patient, whose susceptibility is related to an as yet nonovert immunodeficiency, and those in whom low IgA and IgG2 responses may present a maturational delay of antibody formation (9). Additional evaluation with other polysaccharide vaccines, polysaccharide conjugate vaccines, and in vitro studies of lymphocytes as described by Shackelford et al. (22) may be helpful. Furthermore, in view of the newly developed pneumococcal conjugate vaccines, induction of $\operatorname{IgG} 2$ antipneumococcal antibody production may be possible in the future and provide optimal clinical protection against pneumococcal disease in childhood.

\section{REFERENCES}

1. Rijkers GT, Sanders EAM, Zegers BJM 1993 Anti-capsular polysaccharide antibody deficiency states. Immunodeficiency 5:1-21

2. Insel RA, Anderson PW 1986 Response to oligosaccharide-protein conjugate vaccine against Haemophilus influenzae $\mathrm{b}$ in two patients with $\mathrm{IgG} 2$ deficiency unresponsive to capsular polysaccharide vaccine. N Engl J Med 315:499-503

3. Lane PJ, Maclennan ICM 1986 Impaired IgG2 anti-pneumococcal antibody responses in patients with recurrent infection and normal IgG2 levels but no IgA. Clin Exp Immunol 65:427-433

4. Preud'homme J-L, Hanson LA 1990 IgG subclass deficiency. Immunodefic Rev 2:129-149

5. Ferrante A, Beard LJ, Feldman RG $1990 \mathrm{IgG}$ subclass distribution of antibodies to bacterial and viral antigens. Pediatr Infect Dis J 9:S16-\$24

6. Giebink GS 1989 The microbiology of otitis media. Pediatr Infect Dis J 8:S18-S20

7. Wald ER, Milmoe GJ, Bowen A, Ledesma-Medina J, Salamon N, Bluestone CD 1981 Acute maxillary sinusitis in children. N Engl J Med 304:749-754

8. Freijd A, Hammerström L, Persson MAA, Smith CIE 1984 Plasma antipneumococcal antibody activity of the IgG class and subclasses in otitis prone children. Clin Exp Immunol 56:233-238

9. Sanders EAM, Rijkers GT, Kuis W, Tenbergen-Meekes A-M, de Graeff-Meeder ER, Hiemstra I, Zegers BJM 1993 Defective anti-pneumococcal polysaccharide antibody response in children with recurrent respiratory tract infections. J Allergy Clin Immunol 91:110-119

10. Herrod HG, Gross S, Insel R 1989 Selective antibody deficiency to Haemophilus influenzae type $\mathrm{b}$ capsular polysaccharide vaccination in children with recurrent respiratory tract infection. J Clin Immunol 9:429-434

11. Zegers BJM, Stoop JW, Reerink-Brongers EE, Aalberse RC, Ballieux RE 1975 Serum immunoglobulins in healthy children and adults. Levels of the five classes, expressed in international units per millilitre. Clin Chim Acta 65:319-322

12. Zegers BJM, van der Giessen M, Reerink-Brongers EE, Stoop JW 1980 The serum IgG subclass levels in healthy infants of 13 to 62 wk of age. Clin Chim Acta 101:255-269

13. Hendriksen CFM, van der Gun JW, Kreeftenberg JG 1989 Combined estimation of tetanus and diphtheria antitoxin in human sera by the in vitro toxin-binding inhibition (ToBI) test. J Biol Standard 17:191-200

14. Siber GR, Priehs C, Madore DV 1989 Standardization of antibody assays for measuring the response to pneumococcal infection and immunization. Pediatr Infect Dis J 8:S84-S91

15. Siber GR, Ambrosino DM, Mclver J, Ervin TJ, Schiffman G, Sallan S, Grady GF 1984 Preparation of human hyperimmune globulin to Haemophilus influenzae b, Streptococcus pneumoniae and Neisseria meningitidis. Infect Immun 45:248-254

16. Douglas RM, Paton JC, Duncan SJ, Hansman DJ 1983 Antibody response to pneumococcal vaccination in children younger than five years of age. $J$ Infect Dis 148:131-137

17. Austrian R 1989 Epidemiology of pneumococcal capsular types causing pediatric infections. Pediatr Infect Dis J 8:S21-S22

18. Siber GR, Schur PH, Aisenberg AC, Weitzman SA, Schiffman G 1980 Correlation between serum IgG-2 concentrations and the antibody response to bacterial polysaccharide antigens. N Engl J Med 303:178-182

19. Webster ADB, Latif AAA, Brenner MK, Bird D 1984 Evaluation of test immunisation in the assessment of antibody deficiency syndromes. Br Med J 288:1864-1866

20. Winkelstein JA 1981 The role of complement in the host's defense against Streptococcus pneumoniae. Rev Infect Dis 3:289-298

21. Nahm MH, Macke K, Kwon O-H, Madassery JV, Sherman LA, Scott MG 1990 Immunologic and clinical status of blood donors with subnormal levels of IgG2. J Allery Clin Immunol 85:769-777

22. Shackelford PG, Granoff DM, Polmar SH, Scott MG, Goskowicz MC, Madassery JV, Nahm MH 1990 Subnormal serum concentrations of IgG2 in children with frequent infections associated with varied patterns of immunologic dysfunction. J Pediatr 116:529-538

23. Gross S, Blaiss MS, Herrod HG 1992 Role of the immunoglobulin subclasses and specific determinations in the evaluation of recurrent infection in children. J Pediatr 121:516-522

24. Persson MAA, Brown SE, Steward MW, Hammarström L, Smith CIE, Howard CR, Wahl M, Rynnel-Dagöö B, Lefranc G, Carbonara AO 1988 IgG subclass-associated affinity differences of specific antibodies in humans. J Immunol 140:3875-3879

25. Hetherington SV, Lepow ML 1992 Correlation between antibody affinity and serum bactericidal activity in infants. $J$ Infect Dis 165:753-756

26. Amir J, Liang X, Granoff DM 1990 Variability in the functional activity of vaccineinduced antibody to Haemophilus influenzae type b. Pediatr Res 27:358-364

27. Feinstein A, Richardson N, Taussig MJ 1986 Immunoglobulin flexibility in complement activation. Immunol Today 7:169-174 
28. Lucisano Valim YM, Lachmann PJ 1991 The effect of antibody isotype and antigenic epitope density on the complement-fixing activity of immune complexes: a systematic study using chimaeric anti-NIP antibodies with human Fc regions. Clin Exp Immunol $84: 1-8$

29. Garred P, Michaelsen TE, Aase A 1989 The IgG subclass pattern of complement activation depends on epitope density and antibody and complement concentration. Scand J Immunol 30:379-382

30. Amir J, Scott MG, Nahm MH, Granoff DM 1990 Bactericidal and opsonic activity of $\mathrm{IgG1}$ and IgG2 anticapsular antibodies to Haemophilus influenzae type b. J Infect Dis 162:163-171

31. Lortan JE, Kaniuk AStC, Monteil MA 1993 Relationship of in vitro phagocytosis of serotype 14 Streptococcus pneumoniae to specific class and IgG subclass antibody levels in healthy adults. Clin Exp Immunol 91:54-57

32. Bredius RG, de Vries CEE, Troelstra A, van Alphen L, Weening RS, van de Winkel JGJ, Out TA 1993 Phagocytosis of Staphylococcus aureus and Haemophilus influenzae type B opsonized with polyclonal human IgG1 and $\mathrm{IgG} 2$ antibodies. J Immunol 151:1463-1472

33. Givner LB, Baker CJ, Edwards MS 1987 Type III group B Streptococcus: functional interaction with IgG subclass antibodies. J Infect Dis 155:532-539

34. Chudwin DS, Artrip SG, Schiffman G 1987 Immunoglobulin G class and subclass antibodies to pneumococcal capsular polysaccharides. Clin Immunol Immunopathol 44:114-121

35. van de Winkel JGJ, Capel PJA 1993 Human IgG Fc receptor heterogeneity: molecular aspects and clinical implications. Immunol Today 14:215-221
36. Sanders EAM, van de Winkel JGJ, Rijkers GT, Voorhorst-Ogink MM, de Haas M, Capel PJ, Zegers BJM $1994 \mathrm{Fc} \gamma$ receptor IIA (CD32) heterogeneity in patients with recurrent bacterial respiratory tract infections. J Infect Dis 170:854-861

37. Lue C, Tarkowski A, Mestecky J 1988 Systemic immunization with pneumococcal polysaccharide vaccine induces a predominant IgA2 response of peripheral blood lymphocytes and increases of both serum and secretory anti-pneumococcal antibodies. J Immunol 140:3793-3800

38. Shen L 1992 Receptors for IgA on phagocytic cells. Immunol Res 11:273-277

39. Kilian M, Mestecky J, Russell MW 1988 Defense against involving Fc-dependent functions of immunoglobulin $\mathrm{A}$ and their subversion by bacterial immunoglobulin $\mathrm{A}$ proteases. Microbiol Rev 52:296-303

40. Stewart WW, Kerr MA 1990 The specificity of the human neutrophil IgA receptor ( $\mathrm{Fc} \alpha \mathrm{R})$ determined by measurement of chemiluminescence induced by serum or secretory IgA1 or IgA2. Immunology 71:328-334

41. Chudwin DS, Artrip SG, Schiffman G 1987 Immunoglobulin G class and subclass antibodies to pneumococcal capsular polysaccharides. Clin Immunol Immunopathol 44:114-121

42. Schreiber JR, Barrus V, Cates KL, Siber GR 1986 Functional characterization of human $\mathrm{IgG}$, and $\mathrm{IgA}$ antibody directed to the capsule of Haemophilus influenzae type b. J Infect Dis 153:8-16

43. Bjornson AB, Lobel JS 1987 Direct evidence that decreased serum opsonization of Streptococcus pneumoniae via the alternative complement pathway in sickle cell disease is related to antibody deficiency. J Clin Invest 79:388-398 